\title{
Characterizing the Gap between Accounting Education and Practice: Evidence from Lebanon
}

\author{
Salam Majzoub ${ }^{1,2} \&$ Mehmet Aga ${ }^{2}$ \\ ${ }^{1}$ Faculty of Economics \& Business Administration, Lebanese University, Lebanon \\ ${ }^{2}$ Faculty of Economics and Administrative Science, Cyprus International University Lefkosa, TRNC \\ Correspondence: Salam Majzoub, Faculty of Economics \& Business Administration, Lebanese University, \\ Elkobbeh, Tripoli, Lebanon. Tel: 966-3-851-075. E-mail: salam_adib@hotmail.com
}

Received: September 28, 2015

doi:10.5539/ijbm.v10n12p127
Accepted: October 24, 2015

Online Published: November 25, 2015

URL: http://dx.doi.org/10.5539/ijbm.v10n12p127

\begin{abstract}
Over the past few decades, there has been a widening gap between accounting education and accounting practice. In this article, we present a novel framework that aims to understand this gap by analyzing the accounting educational system and profession from the perspective of the International Accounting Education Standards (IAES). We further consider Lebanon as a case study for thoroughly investigating the accounting educational system and characterizing the gap.

This study is the first of its kind in analyzing the five main groups of stakeholders in this system (fresh graduates, employees, professors, department heads, and employers) and comparing their perspectives about the competencies of accounting graduates. As part of our framework, we introduce a model that captures the interactions between the various stakeholders of the accounting educational and professional system. We then thoroughly probe the various components of this model theoretically, as well as through qualitative and quantitative studies.

Our findings show that while, theoretically, the accounting curriculum incorporates the competencies stipulated by the IAES, in practice, there is a large gap in how the various stakeholders assess the proficiencies of fresh accounting graduates in these competencies. Alarmingly, employers believe that accounting graduates lack the required technical competencies for the job market, while professors, department heads, and students believe that fresh graduates have acquired the required competencies by the time of graduation. In this paper, we investigate the reasons for this gap, characterize it in details, and propose recommendations for bridging it.
\end{abstract}

Keywords: accounting education, accounting practice, IAES, accounting gap, Lebanon

\section{Introduction}

Over the past few decades, there has been an increasing gap between accounting education and accounting practice (Siegel et al., 2010). This gap is due to the fact that even though the accounting profession has evolved with its changing environment, accounting education has not followed pace. Hence, today, we are burdened with a predominantly narrow accounting education that does not fit our contemporary accounting and business environment (Parker, 2001). As a result, fresh accounting graduates lack the skills required for the accounting job market. Furthermore, studies show that accounting education today is lacking on multiple fronts to prepare such graduates for this market, including course content, curriculum, pedagogy, skill development, technology, etc. (Albrecht \& Sack, 2000). This gap has already started taking its toll on accounting education and accounting graduates and is evident in a variety of forms (Albrecht \& Sack, 2000): First, the number and quality of students electing to major in accounting is decreasing rapidly; second, accounting leaders and practicing accountants are saying that accounting education, as currently structured, is outdated, broken, and needs to be modified significantly; third, students from other related disciplines, typically with a major in a business-related field, are filling the positions previously filled by accounting majors because firms are able to train these professionals, who also possess the benefits of other skills, in specific accounting functions (Albrecht \& Sack, 2000).

After realizing the pressing need to bridge the resulting gap, the International Federation of Accountants (IFAC) established an independent standard-setting body, the International Accounting Education Standards Board (IAESB), whose sole role is to study, propose, and monitor standards for accounting education. The recently 
established board has set eight International Education Standards and three International Education Practice Statements.

In this paper, we investigate the gap between accounting education and accounting practice in Lebanon as a case study for a developing country that is deeply integrated with the global market. First, in terms of international students, Lebanon used to be the most attractive Arab country for higher education before the Lebanese civil war (Nahas, 2010). Due to the civil war, which lasted from 1975 to 1990, the percentage of foreign students declined immensely (Nahas, 2010). Second, the country is a source of highly educated labor with $50 \%$ of Lebanese university graduates currently searching for jobs outside their country because the labor market cannot absorb them (Kasparian, 2010; Tabar, 2009; Study, 2009). Arab countries seek the Lebanese labor market for all kinds of employees, with special interest in students holding tertiary degrees. Third, the Lebanese accounting profession is also interwoven with international bodies since the Lebanese Association of Certified Public Accountants (LACPA) is a member of the International Federation of Accountants (IFAC). All of these issues put Lebanon in the heart of the global job market, making it an interesting case study for investigating the gap between the accounting education and profession. Hence, in this paper we ask the following questions:

1) With the increasing effort to bridge the gap between accounting education and accounting practice and in the light of the International Accounting Education Standards set by the IAESB, where does Lebanon stand? Specifically, to what extent are these standards applied in Lebanon and integrated into the accounting curricula of Lebanese universities?

2) Is there a gap between accounting education and accounting practice in Lebanon? If so, where does the gap manifest, and how could it be narrowed to make the Lebanese labor market more appealing to both the global and the local markets?

Answering these questions is challenging for multiple reasons. First, the Lebanese accounting educational and professional systems have not been studied previously, and hence they lack a model that allows us to understand the interactions between their various stakeholders. Second, there is a dearth of past research that has surveyed these stakeholders to understand the status of accounting education and practice in Lebanon.

To overcome these challenges, in this paper, we first introduce a model that captures the interactions between the various stakeholders in the Lebanese accounting markets. We then thoroughly examine the various components of this model to answer our questions. In our study, we consider the International Accounting Education Standards set by the IAESB as a framework.

The IAESB has set eight standards, three of which (IES2, IES3, IES4) describe the competencies that should be acquired during the initial professional development (IPD) of an accountant. Taking these standards as a benchmark, this article studies the fresh graduates' and accounting employees' evaluations of their competencies as described in those standards on one hand; on the other hand, we study the accounting professors', the department heads', and the employers' evaluations of the fresh graduates' competencies. The findings help us characterize the gap between accounting education and practice and suggest solutions to bridge this gap.

The remainder of this paper is organized as follows. The second section reviews the related literature; the third section highlights the hypotheses of our research and introduces the model and the research methodology; the fourth section presents the results and discusses them; and in the fifth and final section, we conclude with our recommendations.

\section{Literature Review}

Previous research studies show that accounting education has failed to keep up with accounting practice, leading to a gap between education and practice (Albrecht \& Sack, 2001; Mohamed \& Lashine, 2003; Dean \& Campbell, 2010). This gap has manifested in a difference between the needs of employers and what accounting graduates are taught in school (Hargadon, 2000). Furthermore, despite the fact that accounting education has improved in the recent past, the quality of accounting graduates is still wanting (Hancock et al., 2010).

Past work has listed various reasons for this gap. First, various studies cite the accounting curriculum as the main factor that has created the gap between what accounting graduates do and what they are expected to do once employed (Novin, Pearson, \& Senge, 1990; Donovan, 2005). For instance, accounting educators focus on the theoretical aspect of training through emphasis on aspects of organizations and society (Chua \& Baxter, 2000); on the other hand, accounting firms value the practical attributes of management accounting education where students are subjected to the technical aspect of training that is relevant in practice (Chua \& Baxter, 2000). Second, accounting education schools produce graduates who are believed to be too focused and narrowly educated and thus unable to meet the demands of various accounting firms (Swanson, 1999; French et al., 2000). 
For example, Klibi and Oussii (2013) conducted a survey and found that employers believe that accounting graduates lack a diverse range of non-technical skills. Third, Bui and Porter (2010) argue that universities' promotion and tenure structure also contributes to the gap. This is because it ranks research productivity above teaching excellence and provides little incentive to lecturers to develop new accounting programs; while universities "hope" that academics do not neglect their teaching responsibilities, they "reward" their performance primarily based on their research and publications. This inevitably leads academics to concentrate on research rather than teaching activities.

Because the accounting curriculum is the main factor contributing to this gap, the debate on the content of this curriculum has raged on for the past twenty-five years, particularly in the US where public accounting has received considerable favor in the country (Kennedy \& Bull, 2000). Critics of the aforementioned curriculum argue that academics have prioritized issues that are not relevant in practice (Siegel et al, 2010; Gamble, Patrick, \& Peach, 2010).

Various nations have adopted different strategies in an attempt to address the curriculum dilemma. For instance, the American Accounting Association (AAA) in the US moved to address the future of accounting education in the country by appointing the Bedford Committee in 1986 (American Accounting Association, 2010). To follow up with the implementation of the Bedford Report, the AAA formed the Accounting Education Change Commission (AECC) in 1993. A myriad of position statements were issued by the committee, including statement number 4 , which required the improvement that accountants must gain early employment experience. Later on, in order to research the structure of higher education for professional accounting and make relevant recommendations, the AAA, together with the American Institute of Certified Public Accountants (AICPA), established the Pathways Commission on Accounting Higher Education (Epstein \& Lee, 2011). The commission provides recommendations on both accounting education and practice. An objective follows each recommendation to provide guidance on the accomplishment of the proposal. The final recommendation of the Pathways Commission 2012 Charting a National Strategy for the Next Generation of Accountants is not directed toward a specific area to be enhanced or changed in the academic or practice communities. Rather, it focuses on establishing an ongoing process to implement these or future recommendations and putting in place the structures and relationships needed to overcome the limitations of periodic efforts to sustain the vitality of accounting education and practice.

Beyond the US, there have been international efforts to bridge this gap and set international accounting standards. The International Accounting Education Standards Board (IAESB) was created by the International Federation of Accountants (IFAC). The IAESB offers essential knowledge, skills, ethics, values, and attitudes, which are all important aspects of becoming a credible accounting professional (Young, 2003; Sikka et al., 2007). Since the profession already has a body in place that ensures all global accounting education institutions adhere to certain acceptable standards and principles, governments - through education departments or sectors - play a critical role in ensuring that this is achieved. Notably, the legitimately established accounting institutions within their borders must meet the required standards already set by the International Accounting Education Standards Board Apart from standard setting, the IAESB has taken up the initiative of making sure it improves the clarity and precision of its standards (Young, 2003; Watson et al., 2001).

The research community has also invested significant effort in studying how to bridge the gap between education and practice by studying different perspectives. Al-Jalily and Taha (2010) suggested that the curriculum of the university should be altered to incorporate the IAES in order to ensure the degree will better serve the profession. Romanus (2014) recommended that there is a need to reorganize, redesign, and restructure the curriculum for the training of accountants to remove the prevailing structures of narrowness and stereotype in the curriculum. Abbasi (2013) proposed and illustrated a systems-based competency model of accounting education that has a global view and comprises the following three stages of curriculum management based on systems' lifecycle: planning and design, implementation, and outcomes assessment. Tudor and Muti (2007) said that the implementation of international education standards is regarded as a challenge at the global level, which requires the adaptation of higher economic education to the exigencies of training for the accounting profession by using new teaching and training modalities. Kavanagh and Drennan (2008) state that, given the expectations of students and the requirements of employers, a much higher level of attention needs to be given to the skills and attributes being prioritized and delivered in accounting programs if accounting graduates are to survive in today's global business environment. By surveying students, professors, and employers, Mandilas et al. (2014) found that all the groups have different perceptions of the curriculum and that the academic accounting curriculum should be improved. In his article, Bryan Howieson (2003) stated that the main growth areas of accounting practice appear to lie in the fields of business advisory services. As such, future accountants will take on the role of "knowledge" workers. 
Wahida Zraa et al. (2011) stated that cooperative learning models of teaching are the most suitable teaching models for the development of professional accounting competencies in the new millennium. Currently, the role of accountants has changed from being a technical job to a more client-oriented job, and their findings indicate that the social interdependence theory and the cooperative learning model are the most appropriate to test for teaching accounting in the new millennium. Nadana and Watty (2014) pinpointed an expectation-performance gap in generic skills in accounting education in Sri Lanka; however, the university educators are aware of employer expectations of graduate accountants, and they acknowledged their low confidence in teaching many generic skills.

While there has been ample research on the accounting education gap internationally, no previous studies have investigated this gap in Lebanon despite significant signs that this gap exists. On one hand, previous studies on Lebanese higher education in general have asserted that this industry may be in jeopardy (Hasrouny, 2011). Furthermore, these previous studies have stated that if Lebanon is to maintain the standing of its higher education system and face the challenges, it should meet the requirements of the knowledge economy at least by implementing the law of higher education quality assurance, and that this law should be a cornerstone of any reforms. On the other hand, the Lebanese accounting job market is in dire need of updating the accounting curricula because fresh accounting graduates are not ready for the accounting profession. In 2015, this is demonstrated by the fact that less than $10 \%$ of the applicants to a government entry position in accounting in Lebanon passed the professional entrance exam (Civil Service Board, n.d.); more specifically, only 216 out of 2,500 applicants passed the exam. This indicates that these fresh accounting graduates do not have the skills required for the profession and are not ready to take an accounting role. Hence, in this paper, we set out to characterize the gap between accounting education and practice in Lebanon and generate insights to bridge it.

\section{Method}

From the above review, it is clear that a gap exists between accounting education and accounting practice. In this paper, we aim to characterize this gap between the Lebanese accounting education and job markets. Specifically, we investigate the following hypothesis:

H1= A gap exists between accounting education and accounting practice in Lebanon.

To verify or negate this hypothesis, we need to investigate it from the perspectives of the various stakeholders. Specifically, we can break the hypothesis into three components:

1) Employers evaluate new graduates as being unprepared to carry an accounting job.

2) Fresh graduates believe that they are ready for the job market.

3) Universities (both professors and department heads) think that they have sufficiently prepared their graduates for the accounting job market.

\subsection{Research Model}

In order to identify and bridge the gap and to test our research hypothesis, we first need to understand the accounting education and job markets in Lebanon. Hence, in this section, we model this system and elaborate on our methodology for studying the various stakeholders in this system. 


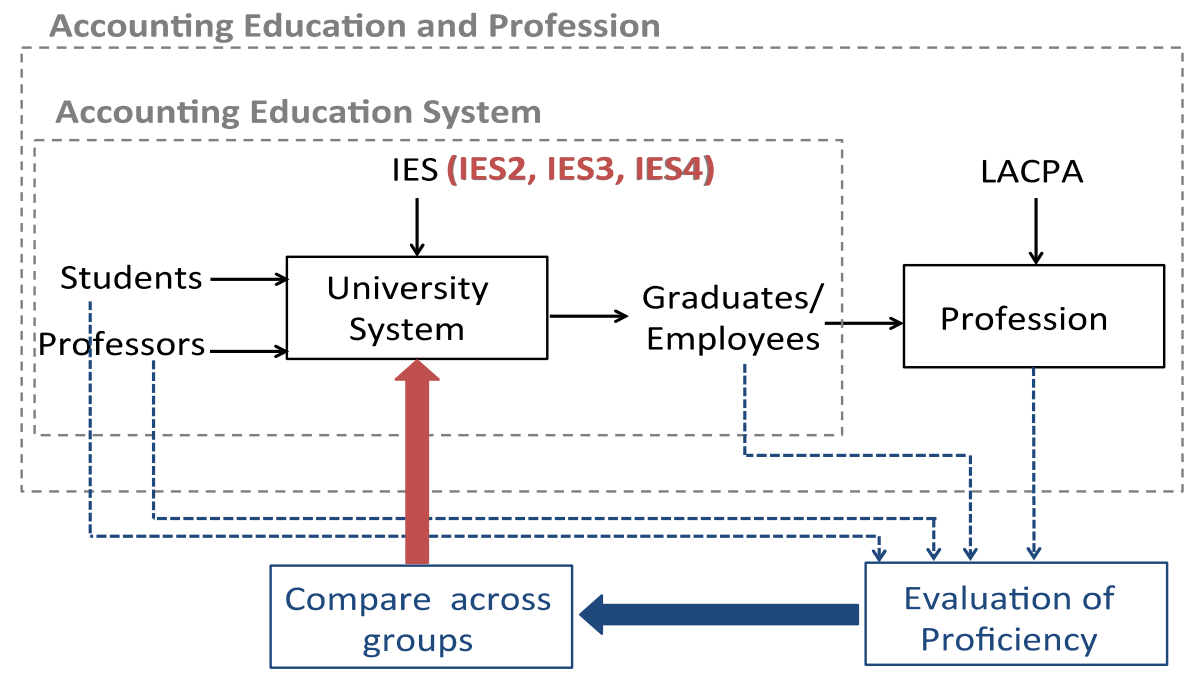

Figure 1. Model for accounting education and profession

The model shows the various stakeholders in the accounting education and professional systems in Lebanon, as well as the interaction between these stakeholders.

Figure 1 shows our model for the accounting educational and professional system. At the core of this system is the university that teaches students and produces accounting professionals. In particular, the inputs to the university system are students and professors, and the output is graduates/employees. This system should be guided by International Education Standards (IES), which are set by the IFAC. This is because the LACPA is part of the IFAC and does not have its own standards; hence, in principle, the LACPA needs to abide by the IES. Specifically, among the IES, the only standards that are tailored toward higher education are the second, third, and fourth standard (IES2, IES3, and IES4). The output of this system is graduates/employees who go into the accounting profession. The profession in Lebanon is governed by the LACPA. Together, the education system and the profession form the accounting education and profession system.

In order to evaluate the effectiveness of the educational system, we need to evaluate the proficiency of the students in the skills dictated by the IES. To do that, we start by evaluating the educational system from the profession's perspective. Specifically, we ask CPA firms (i.e., employers) about how they evaluate new graduates' degree of proficiency. We also ask accounting employees to evaluate their degree of proficiency. Similarly, we ask fresh graduates and professors to evaluate students' degree of proficiency. Then, we compare the answers across groups and analyze them before feeding this analysis back into the university system to improve it.

Now that we understand how the accounting education system and profession work, we can start analyzing it to understand the reasons for the gap between accounting education and practice.

\subsection{The Sample}

We conducted a study involving a total of 450 respondents, including fresh graduates, employees, professors, department heads, and employers. In surveying academics, we sampled from the Lebanese public university system, which encompasses around $40 \%$ of all university students in Lebanon (Center for Educational Research and Development, n.d.). We also conducted interviews with the ex-president of the LACPA and with professionals in the field. Below, we summarize the various categories of our sample, and elaborate on them in the tables that follow. 


\begin{tabular}{lllll}
\hline & Contacted & Replied & Response rate & \\
\hline Graduating students & 250 & 223 & $90 \%$ & Table 1 \\
Professors & 60 & 50 & $84 \%$ & Table 2 \\
Department heads & 29 & 25 & $84 \%$ & Table 3 \\
Professionals & 75 & 67 & $90 \%$ & Table 4 \\
Employees & 90 & 85 & $94 \%$ & Table 5 \\
\hline
\end{tabular}

We note the response rate to our survey is high since most of the candidates were contacted in person. The students and universities were contacted in the months of June and July of 2014 while the practitioners and employees were contacted in August and September of 2014.

Table 1. Demographics of students who participated in the study

\begin{tabular}{|c|c|c|c|c|c|c|}
\hline \multirow[t]{2}{*}{ Major } & & & \multicolumn{3}{|l|}{ Degree } & \multirow[t]{2}{*}{ Total } \\
\hline & & & Bachelor & Master 1 & Master 2 & \\
\hline \multirow[t]{3}{*}{ Accounting } & Gender & Male & 25 & 17 & 9 & 51 \\
\hline & & Female & 59 & 21 & 16 & 96 \\
\hline & & Total & 84 & 38 & 25 & 147 \\
\hline \multirow[t]{3}{*}{ Finance } & Gender & Male & 15 & 2 & 0 & 17 \\
\hline & & Female & 30 & 21 & 8 & 59 \\
\hline & & Total & 45 & 23 & 8 & 76 \\
\hline
\end{tabular}

Table 2. Demographics of professors who participated in the study

\begin{tabular}{|c|c|c|c|c|c|c|c|c|c|}
\hline \multicolumn{3}{|c|}{ Where do you teach? } & \multicolumn{5}{|c|}{ Did you work as accountant? } & \multirow{2}{*}{ Total } & \multirow{2}{*}{$\begin{array}{l}\text { Perce } \\
\mathrm{nt} \\
\%\end{array}$} \\
\hline & & & No & Auditor & Consultant & Accountant & $\mathrm{N} /$ & & \\
\hline \multirow{3}{*}{$\begin{array}{l}\text { Public } \\
\text { university }\end{array}$} & \multirow{3}{*}{$\begin{array}{l}\text { Level of } \\
\text { education }\end{array}$} & $\mathrm{PhD}$ & 8 & 2 & 1 & 1 & & 12 & 38.7 \\
\hline & & Masters & 6 & 1 & 4 & 8 & & 19 & 61.3 \\
\hline & & Total & 14 & 3 & 5 & 8 & & 31 & 100 \\
\hline \multirow[t]{3}{*}{ Private } & \multirow{3}{*}{$\begin{array}{l}\text { Level of } \\
\text { education }\end{array}$} & Doctorate & 1 & 1 & 5 & 1 & 1 & 9 & 47.4 \\
\hline & & Masters & 2 & 1 & 2 & 5 & 0 & 10 & 52.6 \\
\hline & & Total & 3 & 2 & 7 & 6 & 1 & 19 & 100 \\
\hline
\end{tabular}

Table 3. Demographics of department heads who participated in the study

\begin{tabular}{llll}
\hline Kind of university & Level of education & Number & Percent \\
\hline Public & Doctorate & 6 & $100 \%$ \\
Private & Doctorate & 9 & $47.4 \%$ \\
& Master & 10 & $52.6 \%$ \\
& Total & 25 & \\
\hline
\end{tabular}

Table 4. Demographics of practitioners who participated in the study

\begin{tabular}{lll}
\hline & Frequency & Percent \\
\hline Big four & 4 & $6 \%$ \\
Has more than 20 accountants & 8 & $11.9 \%$ \\
Has between 10 and 20 accountants & 16 & $23.9 \%$ \\
Has between 5 and 10 accountants & 24 & $35.8 \%$ \\
Has fewer than 5 accountants & 15 & $22.4 \%$ \\
Total & 67 & $100 \%$ \\
\hline
\end{tabular}


Table 5. Demographics of employees who participated in the study

\begin{tabular}{|c|c|c|c|c|c|c|c|}
\hline & & \multicolumn{6}{|c|}{ Training year to take the CPA exam } \\
\hline & & $\begin{array}{l}\text { First } \\
\text { year }\end{array}$ & $\begin{array}{l}\text { Second } \\
\text { year }\end{array}$ & $\begin{array}{l}\text { Preparing to take CPA } \\
\text { exam }\end{array}$ & $\begin{array}{l}\text { Passed the CPA } \\
\text { exam }\end{array}$ & $\begin{array}{l}\text { No } \\
\text { training }\end{array}$ & Total \\
\hline \multirow{8}{*}{$\begin{array}{l}\text { What degree do you } \\
\text { hold? }\end{array}$} & Bachelor & 7 & 9 & 8 & 0 & 20 & 44 \\
\hline & Master 1 & 2 & 4 & 4 & 0 & 6 & 16 \\
\hline & Master 2 & 1 & 2 & 1 & 1 & 13 & 18 \\
\hline & Technique & 2 & 0 & 0 & 0 & 4 & 6 \\
\hline & Superieur & & & & & & \\
\hline & Licence & 0 & 0 & 1 & 0 & 0 & 1 \\
\hline & Technique & & & & & & \\
\hline & Total & 15 & 14 & 1 & 1 & 43 & 85 \\
\hline
\end{tabular}

\subsection{The Quantitative Questionnaire and Variables}

Recall that our study focuses on evaluating the various competencies dictated by the IES from the perspectives of the various stakeholders in the accounting system in Lebanon. Specifically, we consider three standards (which we detail in Appendix A):

- IES 2, which consists of the technical competencies and is composed of 11 different competencies that the IAESB thought an accountant should acquire during his education, including accounting, managerial, taxation, governance, etc.

- IES 3, which consists of the professional competencies and is composed of four different competencies.

- IES 4, which consists of professional values, ethics, and attitudes, and is composed of three competencies.

All three IES should be acquired during the initial professional development of the accountant. These standards also specify that different competencies need to be acquired at various levels of proficiency. For example, the required level of proficiency of Financial Accounting Reporting is intermediate (i.e., good level of proficiency), while the required level of proficiency of Business Law and Regulations is foundational (i.e., fair level of proficiency).

The questionnaire was extracted from the IES (Appendix A). The same questionnaire was used for all groups. The groups consisting of students and employees were asked to evaluate their own competencies and to scale them, while the groups consisting of accounting professors and department heads were asked to evaluate the graduate students; finally, practitioners were asked to evaluate the fresh graduate employees. The scale used for all groups was a 5-point Likert scale. We consider that if the evaluation is very good the score would be 100, 75 if it is good, 50 if it is fair, 25 if it is weak, and 0 if it is very weak.

The questionnaire was analyzed using SPSS version 21; a Microsoft Excel chart was used to visualize the gap between the means on the variable level.

\subsection{Statistical Analysis Method}

In our research, we rely on statistical tools for two main purposes. First, we leverage statistical tools to test the reliability and validity of our questionnaires. Second, we exploit statistical methods to investigate the gap by comparing among the responses of our various groups. We elaborate on each of these tools below:

\subsubsection{Reliability and Validity of Questionnaires}

In this study, the Cronbach's alpha is used to determine the constructs' reliability and validity. The closer to 1 the Cronbach's alpha is, the more reliable or the more likely that the items are measuring the same construct. We apply the Cronbach's alpha test for each of the 18 areas of competencies covered by IES2, IES3, and IES4.

\subsubsection{Comparing the Groups and Investigating the Gap}

A statistically significant difference between the ratings of competencies indicates a gap between the various categories. For example, a significant difference between how CPA firms view the competencies of fresh graduates and how senior students rate their own competencies indicates a gap between accounting education and practice. Similarly, a difference between how professors view the competencies of students and how the students rate their own competencies indicates a gap between the professors' and students' perspectives.

Hence, in our study, we analyze the statistical significance of the differences at various granularities. Specifically, we analyze the statistical difference at three levels. By doing so, we would be mimicking the standards' 
hierarchical steps. First of all, we check the gap among the groups at a high level, the IES level, and then on a second level we check the gap on the construct level (each group of competencies that are related to each other). Finally, we study the gap on the level of each competency.

We rely on two powerful statistical tools for performing these comparisons: the T-test and the ANOVA (Note 1). The T-test is a statistical tool that can compare between the means of two different groups, while the ANOVA is a statistical tool that enables comparing among the means of three or more groups. Since our groups consist of independent samples, and since we have five different groups, we will perform two kinds of tests. The first one is the ANOVA test to compare all the groups together. Second, we perform independent sample T-tests between the various groups. The T-test allows us to understand the significance of the difference in the evaluation of the competencies of two different groups. In particular, given any two groups and a given competency (or set of competencies), the p-value of the T-test indicates the statistical significance of the difference between the groups' means. A p-value smaller than alpha $=0.05$ indicates that the difference between the groups is statistically significant (Field, 2009).

In sum, we will perform the following statistical analysis:

1) First, we consider aggregate results averaged over all competencies and compare the various groups using an ANOVA test.

2) Then, we analyze the results of the different categories of the competencies independently using independent sample T-tests.

3) Finally, at the finest granularity of analysis, we examine each competency independently using an ANOVA test. Additionally, to help visualize the differences across the different groups, we chart the means of their competencies.

\section{Results and Discussion}

In this section, we describe three different categories of results from our research. The first category consists of a theoretical investigation of curriculum and its incorporation of the IES. The second category consists of qualitative analysis of the gap through interviews with the LACPA's ex-president and accounting professionals. The third category consists of a quantitative study of the gap through the statistical analysis of the surveys as described above. Below, we describe each of these categories in detail.

\subsection{Theoretical Analysis of the Curriculum and Mapping it to the IES}

We thoroughly studied the curriculum of the accounting department at the Lebanese university and mapped it to the IES standards (Appendix B), and we summarize our findings below:

Theoretically, all these standards are present in the curriculum. Specifically, the various courses in the accounting curriculum incorporate all the competencies specified in IES2, IE3, and IE4. For an exact mapping between these competencies and their corresponding courses in the curriculum, please refer to Appendix B.

1) The courses not only revolve around technical competencies in accounting (IES2) but also include all other technical, professional, and ethical competencies (IES3 and IES4).

2) However, we note that in order to acquire all the competencies, it is not sufficient for a student to complete the Bachelor's degree; he/she also needs to complete the Master's degree. In particular, some of these competencies are first incorporated in graduate-level courses, which are required for the Master's degree.

\subsection{Qualitative Analysis of the Gap through Interviews}

Next, we wanted to qualitatively analyze the gap from the perspective of accounting professionals and employers, and understand their perspective on the quality of fresh accounting graduates. To do that, in this section, we analyze the profession section of our model in Figure 1, with a specific focus on the LACPA and accounting professionals.

In general, all the professionals acknowledged the presence of the gap and that most students are more exposed to theory than to practice. Many of the professionals agreed that most of the students lack information about taxes and how to file taxes; they also agreed that students lack critical thinking and the ability to read financial reports. In a question regarding whether or not these professionals believed the IES should be respected by the university curriculum, they indicated that in Lebanon most of our companies are family-owned businesses and that graduates do not really have to acquire all these competencies, with the exception of graduates who will work for the Big Four and other large accounting firms. We note, however, that most of these professionals were unaware of the existence of these standards, and hence we asked them to read these standards before answering 
our questions. Additionally, most of these professionals confirmed that there should be cooperation between the universities and the LACPA in preparing the accounting curriculum and the contents of the courses.

\subsection{Quantitative Analysis of the Gap through Statistical Analysis of Surveys}

Finally, we applied the statistical tools described in the research methodology above to quantitatively study the gap between accounting education and the accounting profession in Lebanon. Recall that this analysis consists of two main parts: (1) testing the reliability and validity of the questionnaires and (2) characterizing the gap by comparing the surveys conducted with the various groups.

Table 7 below shows the results of the Cronbach's alpha for testing the validity and reliability of each of the questionnaire constructs. Cronbach's alpha reliability coefficient normally ranges between 0 and 1 . However, there is actually no lower limit to the coefficient. The closer Cronbach's alpha coefficient is to 1 , the greater the internal consistency of the items in the scale (Gliem \& Gliem, 2003). The table shows that for all groups, Cronbach's alpha is greater than 0.8 except for one item that is 0.620 and a few others that are between 0.7 and 0.8 . This means that the reliability of the majority of our constructs is either excellent or good (above 0.8 ), and the reliability of the rest is acceptable (above 0.7 ) as per Gliem and Gliem (2003).

Table 6. Cronbach's alpha for the questionnaire constructs for each of the groups

\begin{tabular}{|c|c|c|c|c|c|}
\hline Construct & Graduates & Professors & Depart. Head & $\mathrm{CPA}$ & Employees \\
\hline $\begin{array}{l}\text { 2-1-Financial Accounting and } \\
\text { Reporting }\end{array}$ & 0.817 & 0.898 & 0.883 & 0.906 & 0.831 \\
\hline 2-2-Management Accounting & 0.838 & 0.847 & 0.830 & 0.832 & 0.846 \\
\hline $\begin{array}{l}\text { 2-3-Finance and } \quad \text { Financial } \\
\text { Management }\end{array}$ & 0.882 & 0.994 & 0.935 & 0.935 & 0.869 \\
\hline 2-4-Taxation & 0.909 & 0.770 & 0.823 & 0.901 & 0.887 \\
\hline 2-5-Audit and Assurance & 0.950 & 0.893 & 0.914 & 0.938 & 0.916 \\
\hline $\begin{array}{l}\text { 2-6-Governance, Risk Management, } \\
\text { and Internal Control }\end{array}$ & 0.871 & 0.894 & 0.810 & 0.920 & 0.878 \\
\hline 2-7-Business Laws and Regulations & 0.838 & ---- & 0.789 & 0.770 & 0.945 \\
\hline 2-8-Information Technology & 0.932 & ---- & 0.933 & 0.944 & 0.842 \\
\hline $\begin{array}{l}\text { 2-9-Business and Organizational } \\
\text { Environment }\end{array}$ & 0.821 & ---- & 0.905 & 0.925 & 0.817 \\
\hline 1-10-Economics & 0.890 & ----- & 0.906 & 0.834 & 0.836 \\
\hline 2-11-Business & 0.813 & ----- & 0.871 & 0.909 & 0.917 \\
\hline Management & & & & & \\
\hline 3-1-Intellectual & 0.868 & 0.913 & 0.949 & 0.761 & 0.797 \\
\hline 3-2-Personal & 0.880 & 0.859 & 0.926 & 0.900 & 0.835 \\
\hline 3-3-Interpersonal and & 0.902 & 0.938 & 0.951 & 0.867 & 0.865 \\
\hline Communication & & & & & \\
\hline 3-4-Organizational & 0.879 & 0.897 & 0.926 & 0.855 & 0.864 \\
\hline $\begin{array}{l}\text { 4-1-Professional Skepticism and } \\
\text { Professional Judgment }\end{array}$ & 0.816 & 0.886 & 0.940 & 0.737 & 0.620 \\
\hline 4-2-Ethical Principles & 0.919 & 0.951 & 0.972 & 0.928 & 0.901 \\
\hline $\begin{array}{l}\text { 4-3-Commitment to } \\
\text { Public Interest }\end{array}$ & 0.914 & 0.918 & 0.924 & 0.944 & 0.909 \\
\hline
\end{tabular}

Next, we investigate the existence of the gap by analyzing the group surveys at three levels of hierarchy, mimicking the hierarchical structure of the standards themselves.

\subsubsection{Level 1: Aggregate Analysis across Groups (ANOVA Test) by IES}

We start by comparing the evaluation of the different groups at the level of IES, using an ANOVA test. This provides us with a bird's eye view of the statistical significance of the different groups' evaluations of the IES.

The following tables present the ANOVA test results on the level of the standards. The mean on the level of IES is calculated for each group; then, an ANOVA test is used to find out if the null hypothesis (i.e., that all groups have the same evaluation for a given IES) is accepted or rejected. 
Table 7. Results of the anova test for IES 2 technical competencies (TC)

\begin{tabular}{lllllllll}
\hline IES 2 (TC) & N & Mean & Std. Deviation & \multicolumn{2}{c}{$95 \%$ Confidence Interval for Mean } & Min & Max & P-value \\
& & & \multicolumn{7}{c}{ Lower Bound } & Upper Bound & & & \\
\hline Students & 223 & 62.54 & 13.58 & 60.75 & 64.33 & 25 & 88 & \\
CPA firms & 67 & 41.43 & 16.54 & 37.40 & 45.47 & 2 & 78 & \\
Employees & 85 & 63.19 & 14.47 & 60.07 & 66.31 & 26 & 100 & $<0.0001$ \\
Accounting Professors & 50 & 60.80 & 16.82 & 56.02 & 65.58 & 34 & 91 & \\
Department heads & 25 & 67.40 & 15.86 & 60.85 & 73.95 & 40 & 90 & \\
\hline
\end{tabular}

Table 8. Results of the anova test for IES 3 professional competencies (PC)

\begin{tabular}{|c|c|c|c|c|c|c|c|c|}
\hline \multirow[t]{2}{*}{ IES 3 (PC) } & \multirow[t]{2}{*}{$\mathrm{N}$} & \multirow[t]{2}{*}{ Mean } & \multirow[t]{2}{*}{ Std. Deviation } & \multicolumn{2}{|c|}{ 95\% Confidence Interval for Mean } & \multirow[t]{2}{*}{ Min } & \multirow[t]{2}{*}{ Max } & \multirow[t]{2}{*}{ P-value } \\
\hline & & & & Lower Bound & Upper Bound & & & \\
\hline Students & 223 & 70.33 & 14.66 & 68.40 & 72.27 & 29 & 96 & \\
\hline CPA firms & 67 & 56.00 & 12.76 & 52.89 & 59.11 & 24 & 80 & \\
\hline Employees & 85 & 70.71 & 14.06 & 67.67 & 73.74 & 27 & 94 & $<0.0001$ \\
\hline Accounting professors & 50 & 57.52 & 18.10 & 52.38 & 62.66 & 14 & 89 & \\
\hline Department heads & 25 & 60.28 & 21.95 & 51.22 & 69.34 & 14 & 96 & \\
\hline
\end{tabular}

Table 9. Results of the ANOVA Test for IES 4 professional values, ethics, and attitude competencies (EC)

\begin{tabular}{|c|c|c|c|c|c|c|c|c|}
\hline \multirow[t]{4}{*}{ IES 4 (EC) } & \multirow[t]{4}{*}{$\mathrm{N}$} & \multirow[t]{4}{*}{ Mean } & \multirow{4}{*}{$\begin{array}{l}\text { Std. } \\
\text { Deviation }\end{array}$} & $95 \%$ & Confidence & \multirow[t]{4}{*}{ Min } & \multirow[t]{4}{*}{$\operatorname{Max}$} & \multirow[t]{4}{*}{ P-value } \\
\hline & & & & \multicolumn{2}{|c|}{ Interval for Mean } & & & \\
\hline & & & & Lower & Upper & & & \\
\hline & & & & Bound & Bound & & & \\
\hline Students & 223 & 65.51 & 17.41 & 63.21 & 67.80 & 24 & 100 & \\
\hline CPA firms & 67 & 61.37 & 16.01 & 57.47 & 65.28 & 7 & 98 & \\
\hline Employees & 85 & 73.08 & 16.14 & 69.60 & 76.56 & 28 & 100 & $<0.0001$ \\
\hline $\begin{array}{l}\text { Accounting } \\
\text { professors }\end{array}$ & 50 & 57.94 & 20.29 & 52.17 & 63.71 & 1 & 92 & \\
\hline $\begin{array}{l}\text { Department } \\
\text { heads }\end{array}$ & 25 & 61.28 & 24.91 & 51.00 & 71.56 & 1 & 95 & \\
\hline
\end{tabular}

Tables 7,8 , and 9 show us that the null hypothesis is rejected because the p-value is $<0.0001$, which means that the groups did not have the same evaluation for any of the competencies that should be acquired by the students on an aggregated level. These tables were able to provide an overall picture of the rejection of the null hypothesis. The results of the high-level study show that there is a gap in all IES. However, it is worth mentioning that the employees have evaluated themselves after they started working, while the CPA firms were asked to evaluate the fresh graduates.

While the ANOVA provides us with a sense of discrepancy among all the various groups, it does not provide us with granular information about which groups are the most disparate with respect to each other. Hence, in our context, it enables us to detect the presence of the gap, but does not specify between which groups the gap exists.

To identify the groups between which this gap exists, we perform a follow-up test called the Tukey, honest significant difference (HSD). The Tukey HSD takes all five of our groups as input and categorizes them into homogeneous subsets; that is, it identifies which of the groups provide similar responses and which of them differ from each other. Hence, by performing the Tukey HSD on our survey answers, we determined that there are two main homogenous categories of groups:

- The first category consists of the CPA firms alone.

- The second category consists of accounting professors, students, department heads, and employees.

4.3.2 Level 2: Analysis at the Construct Level (T-test)

After finding out in level 1 that there is a significant difference among the evaluations of the different groups at 
the level of the IES, and since we know that the different IES are composed of many constructs, we now zoom in on these constructs to perform a more detailed study.

In order to perform this task, we needed to perform a series of independent sample T-tests. Note that T-tests are pairwise tests that identify the differences in means between any two given groups. Rather than performing these tests between all possible pairwise combinations in the five groups, we only perform them among groups that belong to separate homogeneous categories, as identified by the Tukey HSD test described above. In particular, we perform independent T-tests where we compare the responses of the CPA firms to the responses of each of the remaining four groups, as indicated by each of the arrows in Figure 2.

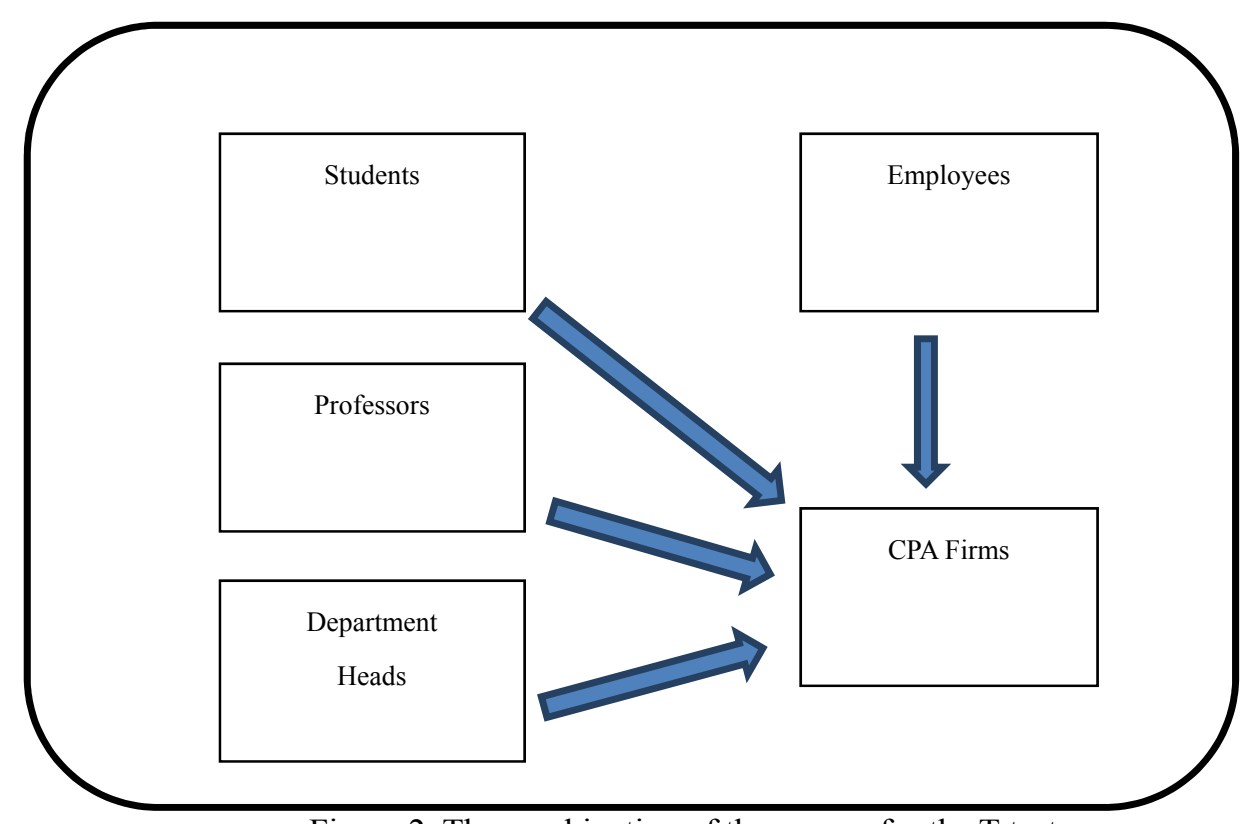

Figure 2. The combination of the groups for the T-tests

Before we proceed to the T-test analysis and results, we should explain that whenever the null hypothesis is confirmed, this means that the studied groups' evaluations of the competencies are the same, while when the null hypothesis is rejected, this means that a gap exists and the evaluations of the studied groups are different.

Comparing between graduating students and professionals (CPA firms). We first start by comparing the evaluations of the graduate students to those of employers. We perform these comparisons at the level of the IES (i.e., IES2, IE3, IES4) as well as at the level of each of the constructs of these IES. Tables 11-14 show our results. We summarize our findings from these comparisons below:

- Table 11 shows that on the high level, i.e., on the level of the standards, the null hypothesis that the students and the firms have the same evaluation is rejected for IES 2 and IES 3, while at the $5 \%$ confidence level for IES 4 , it is not rejected.

- Tables 12 and 13 indicate that the null hypothesis is rejected for all constructs of IES2 and IES3 between the students and the firms.

- Table 14 shows that the null hypothesis is rejected for the first construct between the students and the firms, while the null hypothesis is not rejected for both the second and third construct. 
Table 10. T-test between students and employers at the IES level

\begin{tabular}{llllllll}
\hline & \multicolumn{2}{l}{ Students $(\mathrm{n}=223)$} & \multicolumn{2}{l}{ CPA Firms $(\mathrm{n}=67)$} & \multicolumn{2}{l}{ T-test } & \\
& Mean & Std. Deviation & Mean & Std. Deviation & $\mathrm{t}$ & $\mathrm{df}$ & P-value \\
\hline TC & 62.54 & 13.58 & 41.43 & 16.54 & 10.59 & 288 & .000 \\
PC & 70.33 & 14.66 & 56.00 & 12.76 & 7.22 & 288 & .000 \\
EC & 65.51 & 17.41 & 61.37 & 16.01 & 1.73 & 288 & .084 \\
\hline
\end{tabular}

Table 11. T-test between students and employers for IES2 at the construct level

\begin{tabular}{llllllll}
\hline & \multicolumn{2}{l}{ Students $(\mathrm{n}=223)$} & \multicolumn{2}{l}{ CPA Firms $(\mathrm{n}=67)$} & \multicolumn{2}{l}{ T-test } & \\
& Mean & Std. Deviation & Mean & Std. Deviation & $\mathrm{t}$ & $\mathrm{df}$ & P-value \\
\hline TC1 & 63.61 & 15.99 & 42.96 & 17.25 & 9.10 & 288 & .000 \\
TC2 & 68.48 & 18.91 & 37.73 & 16.36 & 12.02 & 288 & .000 \\
TC3 & 67.09 & 20.87 & 38.06 & 19.07 & 10.18 & 288 & .000 \\
TC4 & 55.52 & 24.00 & 45.15 & 25.08 & 3.07 & 288 & .002 \\
TC5 & 62.40 & 28.47 & 39.97 & 25.22 & 5.80 & 288 & .000 \\
TC6 & 58.67 & 22.48 & 37.99 & 22.68 & 6.59 & 288 & .000 \\
TC7 & 61.79 & 21.00 & 46.37 & 21.26 & 5.26 & 288 & .000 \\
TC8 & 58.30 & 25.06 & 45.87 & 22.93 & 3.63 & 288 & .000 \\
TC9 & 62.13 & 18.39 & 37.72 & 18.82 & 9.47 & 288 & .000 \\
TC10 & 63.41 & 22.44 & 41.67 & 18.84 & 7.20 & 288 & .000 \\
TC11 & 67.00 & 15.16 & 41.34 & 16.98 & 11.80 & 288 & .000 \\
\hline
\end{tabular}

Table 12. T-test between students and employers for IES 3 at the construct level

\begin{tabular}{llllllll}
\hline \multicolumn{3}{c}{ Students $(\mathrm{n}=223)$} & \multicolumn{2}{c}{ CPA Firms $(\mathrm{n}=67)$} & \multicolumn{2}{c}{ T-test } \\
& Mean & Std. Deviation & Mean & Std. Deviation & $\mathrm{t}$ & $\mathrm{df}$ & P-value \\
\hline PC1 & 67.17 & 17.90 & 47.31 & 13.8 & 8.36 & 288 & .000 \\
PC2 & 71.07 & 16.85 & 57.61 & 15.88 & 5.81 & 288 & .000 \\
PC3 & 72.11 & 17.43 & 62.07 & 14.67 & 4.28 & 288 & .000 \\
PC4 & 71.17 & 17.97 & 57.43 & 14.82 & 5.70 & 288 & .000 \\
\hline
\end{tabular}

Table 13. T-test between students and employers for IES 4 at the construct level

\begin{tabular}{llllllll}
\hline & \multicolumn{2}{l}{ Students $(\mathrm{n}=223)$} & \multicolumn{2}{l}{ CPA Firms $(\mathrm{n}=67)$} & \multicolumn{2}{l}{ T-test } \\
& Mean & Std. Deviation & Mean & Std. Deviation & $\mathrm{t}$ & $\mathrm{df}$ & P-value \\
\hline EC1 & 65.55 & 21.80 & 57.49 & 16.2 & 2.80 & 288 & .005 \\
EC2 & 66.84 & 20.09 & 64.22 & 17.56 & 0.96 & 288 & .337 \\
EC3 & 64.39 & 19.91 & 62.91 & 19.36 & 0.54 & 288 & .591 \\
\hline
\end{tabular}

Comparing between accounting professors and professionals (CPA firms). Next, we compare the evaluations of the accounting professors to those of professionals in a similar fashion. Tables 15-18 show the results, which we summarize below:

- Table 15 demonstrates that on the high level, i.e., on the level of the standards, the null hypothesis that the professors and the firms have the same answers (i.e., evaluating the fresh graduates similarly) is rejected for IES2, while it is not rejected for IES3 and IE4 at the 5\% confidence level.

- As aforementioned, the IES 2 has 11 constructs, each of which is composed of different competencies. The accounting professors only evaluated the students on six constructs that are related to accounting; this is why we only find six constructs in the comparison between professors and CPA firms. Table 16 illustrates that the null hypothesis is rejected for all constructs between the professors and the firms.

Table 17 expresses that the null hypothesis at the $5 \%$ confidence level is only rejected in the first construct and is not rejected for the other three constructs between the professors and the firms.

- Table 18 shows that the null hypothesis is not rejected. 
Table 14. T-test between professors and employers on the IES level

\begin{tabular}{llllllll}
\hline & \multicolumn{2}{l}{ Accounting professors $(\mathrm{n}=50)$} & \multicolumn{2}{l}{ CPA firms $(\mathrm{n}=67)$} & \multicolumn{2}{l}{ T-test } & \\
& Mean & Std. Deviation & Mean & Std. Deviation & t & df & P-value \\
\hline TC & 60.80 & 16.82 & 41.43 & 16.54 & 6.22 & 115 & .000 \\
PC & 57.52 & 18.10 & 56.00 & 12.76 & .53 & 115 & .595 \\
EC & 57.94 & 20.29 & 61.37 & 16.01 & -1.02 & 115 & .308 \\
\hline
\end{tabular}

Table 15. T-test for IES 2 between professors and employers on the construct level

\begin{tabular}{llllllll}
\hline & \multicolumn{2}{l}{ Accounting professors $(\mathrm{n}=50)$} & \multicolumn{2}{l}{ CPA firms $(\mathrm{n}=67)$} & \multicolumn{2}{l}{ T-test } \\
& Mean & Std. Deviation & Mean & Std. Deviation & $\mathrm{t}$ & $\mathrm{df}$ & P-value \\
\hline TC1 & 61.15 & 19.18 & 42.96 & 17.25 & 5.32 & 113 & .000 \\
$\mathrm{TC} 2$ & 60.92 & 18.10 & 37.73 & 16.36 & 7.17 & 113 & .000 \\
$\mathrm{TC} 3$ & 71.04 & 21.62 & 38.06 & 19.07 & 7.02 & 89 & .000 \\
TC4 & 55.74 & 16.55 & 45.15 & 25.08 & 2.53 & 112 & .013 \\
TC5 & 65.38 & 20.77 & 39.97 & 25.22 & 5.72 & 113 & .000 \\
TC6 & 58.42 & 20.17 & 37.99 & 22.68 & 4.99 & 113 & .000 \\
\hline
\end{tabular}

Table 16. T-test for IES 3 between professors and employers on the construct level

\begin{tabular}{llllllll}
\hline & \multicolumn{2}{l}{ Accounting professors $(\mathrm{n}=50)$} & \multicolumn{2}{l}{ CPA firms $(\mathrm{n}=67)$} & \multicolumn{2}{l}{ T-test } \\
& Mean & Std. Deviation & Mean & Std. Deviation & t & df & P-value \\
\hline PC1 & 56.44 & 19.92 & 47.31 & 13.8 & 2.93 & 115 & .004 \\
PC2 & 57.76 & 16.76 & 57.61 & 15.88 & .05 & 115 & .961 \\
PC3 & 58.76 & 21.54 & 62.07 & 14.67 & -.99 & 115 & .324 \\
PC4 & 57.14 & 19.61 & 57.43 & 14.82 & -.09 & 115 & .927 \\
\hline
\end{tabular}

Table 17. T-test for IES4 between professors and employers on the construct level

\begin{tabular}{llllllll}
\hline & \multicolumn{2}{l}{ Accounting professors $(\mathrm{n}=50)$} & \multicolumn{2}{l}{ CPA firms $(\mathrm{n}=67)$} & \multicolumn{2}{l}{ T-test } & \\
& Mean & Std. Deviation & Mean & Std. Deviation & $\mathrm{t}$ & df & P-value \\
\hline EC1 & 55.60 & 19.60 & 57.49 & 16.20 & -.57 & 115 & .569 \\
EC2 & 57.20 & 21.69 & 64.22 & 17.56 & -1.93 & 115 & .055 \\
EC3 & 61.24 & 23.84 & 62.91 & 19.36 & -.42 & 115 & .677 \\
\hline
\end{tabular}

Comparing between department heads and professionals. We use T-tests to compare the evaluations of department heads to those of professionals in tables 19-22 and summarize our findings below:

- Table 19 shows that on the high level, i.e., on the level of the standards, the null hypothesis that the department heads and the firms have the same answers is rejected for IES2, while it is confirmed for IES3 and IES4 at the 5\% confidence level.

- Table 20 shows that the null hypothesis is rejected for all constructs of IES2 between the department heads and the firms.

- Table 21 demonstrates that the null hypothesis at the $5 \%$ confidence level is only rejected in the first construct, while it is not rejected for the other three constructs between the department heads and the firms.

- Table 22 shows that the null hypothesis is not rejected.

Table 18. T-test between department heads and employers on the IES level

\begin{tabular}{llllllll}
\hline & \multicolumn{2}{l}{ Department heads $(\mathrm{n}=25)$} & \multicolumn{2}{l}{ CPA firms $(\mathrm{n}=67)$} & \multicolumn{2}{l}{ T-test } & \\
& Mean & Std. Deviation & Mean & Std. Deviation & $\mathrm{t}$ & $\mathrm{df}$ & P-value \\
\hline TC & 67.40 & 15.86 & 41.43 & 16.54 & 6.77 & 90 & .000 \\
PC & 60.28 & 21.95 & 56.00 & 12.76 & 1.16 & 90 & .249 \\
EC & 61.28 & 24.91 & 61.37 & 16.01 & -.02 & 90 & .983 \\
\hline
\end{tabular}


Table 19. T-test for IES2 between dept. heads and employers on the construct level

\begin{tabular}{llllllll}
\hline & \multicolumn{2}{c}{ Department heads $(\mathrm{n}=25)$} & \multicolumn{2}{l}{ CPA firms $(\mathrm{n}=67)$} & \multicolumn{2}{c}{ T-test } \\
& Mean & Std. Deviation & Mean & Std. Deviation & $\mathrm{t}$ & $\mathrm{df}$ & P-value \\
\hline TC1 & 69.76 & 17.51 & 42.96 & 17.25 & 6.60 & 90 & .000 \\
TC2 & 68.36 & 17.95 & 37.73 & 16.36 & 7.78 & 90 & .000 \\
TC3 & 71.80 & 21.50 & 38.06 & 19.07 & 7.29 & 90 & .000 \\
TC4 & 61.40 & 16.80 & 45.15 & 25.08 & 2.99 & 90 & .004 \\
TC5 & 71.64 & 22.73 & 39.97 & 25.22 & 5.50 & 90 & .000 \\
TC6 & 64.64 & 17.50 & 37.99 & 22.68 & 5.31 & 90 & .000 \\
TC7 & 70.28 & 16.19 & 46.37 & 21.26 & 5.09 & 90 & .000 \\
TC8 & 58.92 & 23.72 & 45.87 & 22.93 & 2.41 & 90 & .018 \\
TC9 & 63.36 & 22.31 & 37.72 & 18.82 & 5.52 & 90 & .000 \\
TC10 & 72.44 & 23.05 & 41.67 & 18.84 & 6.55 & 90 & .000 \\
TC11 & 70.00 & 16.58 & 41.34 & 16.98 & 7.25 & 90 & .000 \\
\hline
\end{tabular}

Table 20. T-test for IES 3 between dept. heads and employers on the construct level

\begin{tabular}{lllllllll}
\hline & \multicolumn{2}{c}{ Department heads $(\mathrm{n}=25)$} & \multicolumn{2}{l}{ CPA firms $(\mathrm{n}=67)$} & \multicolumn{2}{l}{ T-test } \\
& Mean & Std. Deviation & Mean & Std. Deviation & $\mathrm{t}$ & $\mathrm{df}$ & P-value \\
\hline PC1 & 60.68 & 24.65 & 47.31 & 13.8 & 3.28 & 90 & .001 \\
PC2 & 59.08 & 19.32 & 57.61 & 15.88 & .37 & 90 & .711 \\
PC3 & 60.92 & 24.73 & 62.07 & 14.67 & -.28 & 90 & .784 \\
PC4 & 60.76 & 22.96 & 57.43 & 14.82 & .82 & 90 & .416 \\
\hline
\end{tabular}

Table 21. T-test for IES 4 between dept. heads and employers on the construct level

\begin{tabular}{lllllllll}
\hline & \multicolumn{2}{l}{ Department heads $(\mathrm{n}=25)$} & \multicolumn{2}{l}{ CPA firms $(\mathrm{n}=67)$} & \multicolumn{2}{l}{ T-test } \\
& Mean & Std. Deviation & Mean & Std. Deviation & $\mathrm{t}$ & $\mathrm{df}$ & P-value \\
\hline EC1 & 59.60 & 23.20 & 57.49 & 16.2 & .49 & 90 & .625 \\
EC2 & 62.88 & 26.39 & 64.22 & 17.56 & -.28 & 90 & .778 \\
EC3 & 61.56 & 27.72 & 62.91 & 19.36 & -.26 & 90 & .793 \\
\hline
\end{tabular}

Comparing between professionals and employees. Before starting with the analysis of these results, it is very important to mention that the CPA firms were asked to evaluate fresh graduate students while employees were asked to evaluate themselves after they had started working. Tables 23-26 show the results of the T-test comparisons between these two groups. The importance of these tables resides in the evaluation of the employees. The employees are evaluating their competencies after they started working. Since most of the means are around 70 , these results show that employees consider that they possess most of the required competencies except for the competencies that are related to the non-accounting technical competencies.

Table 22. T-test between employers and employees on the IES level

\begin{tabular}{llllllll}
\hline & \multicolumn{2}{l}{ CPA firms $(\mathrm{n}=67)$} & \multicolumn{2}{l}{ Employees $(\mathrm{n}=85)$} & \multicolumn{2}{l}{ T-test } & \\
& Mean & Std. Deviation & Mean & Std. Deviation & $\mathrm{t}$ & $\mathrm{df}$ & P-value \\
\hline TC & 41.43 & 16.54 & 63.19 & 14.47 & -8.64 & 150 & .000 \\
PC & 56.00 & 12.76 & 70.71 & 14.06 & -6.67 & 150 & .000 \\
EC & 61.37 & 16.01 & 73.08 & 16.14 & -4.46 & 150 & .000 \\
\hline
\end{tabular}


Table 23. T-test for IES 2 between employers and employees on the construct level

\begin{tabular}{llllllll}
\hline & \multicolumn{2}{l}{ CPA firms $(\mathrm{n}=67)$} & \multicolumn{2}{l}{ Employees $(\mathrm{n}=85)$} & \multicolumn{2}{l}{ T-test } & \\
& Mean & Std. Deviation & Mean & Std. Deviation & $\mathrm{t}$ & df & P-value \\
\hline TC1 & 42.96 & 17.25 & 69.27 & 17.42 & -9.29 & 150 & .000 \\
TC2 & 37.73 & 16.36 & 64.20 & 19.65 & -8.87 & 150 & .000 \\
TC3 & 38.06 & 19.07 & 61.88 & 18.26 & -7.83 & 150 & .000 \\
TC4 & 45.15 & 25.08 & 70.29 & 20.15 & -6.86 & 150 & .000 \\
TC5 & 39.97 & 25.22 & 66.56 & 22.72 & -6.83 & 150 & .000 \\
TC6 & 37.99 & 22.68 & 59.53 & 20.32 & -6.16 & 150 & .000 \\
TC7 & 46.37 & 21.26 & 63.80 & 26.00 & -4.44 & 150 & .000 \\
TC8 & 45.87 & 22.93 & 67.58 & 18.31 & -6.49 & 150 & .000 \\
TC9 & 37.72 & 18.82 & 55.32 & 18.06 & -5.85 & 150 & .000 \\
TC10 & 41.67 & 18.84 & 56.46 & 20.44 & -4.58 & 150 & .000 \\
TC11 & 41.34 & 16.98 & 61.41 & 20.39 & -6.48 & 150 & .000 \\
\hline
\end{tabular}

Table 24. T-test for IES 3 between employers and employees on the construct level

\begin{tabular}{llllllll}
\hline & \multicolumn{2}{l}{ CPA firms $(\mathrm{n}=67)$} & \multicolumn{2}{c}{ Employes $(\mathrm{n}=85)$} & \multicolumn{2}{c}{ T-test } & \\
& Mean & Std. Deviation & Mean & Std. Deviation & $\mathrm{t}$ & $\mathrm{df}$ & P-value \\
\hline PC1 & 47.31 & 13.80 & 73.29 & 15.86 & -10.61 & 150 & .000 \\
PC2 & 57.61 & 15.88 & 71.75 & 16.07 & -5.42 & 150 & .000 \\
PC3 & 62.07 & 14.67 & 69.14 & 16.91 & -2.71 & 150 & .008 \\
PC4 & 57.43 & 14.82 & 68.75 & 17.37 & -4.25 & 150 & .000 \\
\hline
\end{tabular}

Table 25. T-test for IES 4 between employers and employees on the construct level

\begin{tabular}{llllllll}
\hline & \multicolumn{2}{l}{ CPA firms $(\mathrm{n}=67)$} & \multicolumn{2}{l}{ Employees $(\mathrm{n}=85)$} & \multicolumn{2}{l}{ T-test } \\
& Mean & Std. Deviation & Mean & Std. Deviation & $\mathrm{t}$ & $\mathrm{df}$ & P-value \\
\hline EC1 & 57.49 & 16.20 & 71.18 & 16.56 & -5.11 & 150 & .000 \\
EC2 & 64.22 & 17.56 & 73.85 & 18.57 & -3.25 & 150 & .001 \\
EC3 & 62.91 & 19.36 & 74.55 & 19.28 & -3.69 & 150 & .000 \\
\hline
\end{tabular}

\subsubsection{Level 3: Analysis at the Level of Specific Competencies}

After performing the t-test and finding out that the null hypothesis does not hold most of the time, a more in-depth study on the competency level was conducted.

Table 27 and Chart 1 show the results of the ANOVA test for the competencies of IES 2. The table exhibits the means of the evaluation of each group per competency, and the last column shows the p-value. When the p-value is less than 0.05 , it means that the different groups have different evaluations for the competencies but it does not say where the difference lies. In other words, it does not explain if the difference is between professors and fresh graduates, or between professors and professionals. However, by looking at the chart, we see that the means of the professors, department heads, and students are overlapping, while the means of the professionals are farther away with few exceptions. Hence, we can claim that the difference in evaluation is between the stakeholders that represent the universities on the one hand and those that represent the professionals on the other hand. All stakeholders agree on some of the competencies of the fourth construct (p-value $>0.05$ ). We note, however, that a p-value greater than 0.05 only means that the different groups agree in their evaluations of the corresponding competency, but it does not mean that the competency at hand has been acquired. 
Table 26. ANOVA test for IES 2 on the competency level

\begin{tabular}{|c|c|c|c|c|c|}
\hline Competencies IES2 & Students & $\mathrm{CPA}$ & Prof & Dept. head & p-value \\
\hline Construct1 V1 & 73.09 & 51.49 & 72.40 & 76.00 & 0.000 \\
\hline Construct1 V2 & 56.61 & 38.06 & 60.94 & 72.00 & 0.000 \\
\hline Construct1 V3 & 68.95 & 50.75 & 68.75 & 79.00 & 0.000 \\
\hline Construct1 V4 & 64.57 & 46.64 & 60.94 & 70.00 & 0.000 \\
\hline Construct1 V5 & 61.32 & 35.45 & 57.81 & 71.00 & 0.000 \\
\hline Construct1 V6 & 56.73 & 35.07 & 45.83 & 50.00 & 0.000 \\
\hline Construct2 V1 & 75.90 & 45.15 & 68.75 & 75.00 & 0.000 \\
\hline Construct2 V2 & 69.17 & 40.67 & 59.90 & 63.00 & 0.000 \\
\hline Construct2 V3 & 59.87 & 31.34 & 53.13 & 67.00 & 0.000 \\
\hline Construct2 V4 & 68.39 & 33.21 & 61.46 & 68.00 & 0.000 \\
\hline Construct $3 \mathrm{~V} 1$ & 71.08 & 39.93 & 68.75 & 69.00 & 0.000 \\
\hline Construct3 V2 & 72.65 & 42.91 & 73.96 & 75.00 & 0.000 \\
\hline Construct 3 V3 & 66.48 & 41.04 & 75.00 & 76.00 & 0.000 \\
\hline Construct3 V4 & 63.00 & 34.70 & 69.79 & 71.00 & 0.000 \\
\hline Construct3 V5 & 62.22 & 31.72 & 67.71 & 68.00 & 0.000 \\
\hline Construct4 V1 & 58.97 & 55.97 & 65.76 & 70.00 & 0.06 \\
\hline Construct4 V2 & 68.16 & 52.61 & 69.15 & 72.00 & 0.000 \\
\hline Construct4 V3 & 52.58 & 36.94 & 50.00 & 54.00 & 0.000 \\
\hline Construct4 V4 & 46.52 & 40.67 & 45.11 & 56.00 & 0.149 \\
\hline Construct4 V5 & 51.35 & 39.55 & 46.74 & 55.00 & 0.021 \\
\hline Construct5 V1 & 59.64 & 38.43 & 57.45 & 65.00 & 0.000 \\
\hline Construct5 V2 & 66.14 & 43.28 & 72.87 & 78.00 & 0.000 \\
\hline Construct5 V3 & 61.66 & 41.04 & 69.68 & 74.00 & 0.000 \\
\hline Construct5 V4 & 61.66 & 36.57 & 61.98 & 69.00 & 0.000 \\
\hline Construct6 V1 & 58.07 & 36.94 & 59.90 & 63.00 & 0.000 \\
\hline Construct6 V2 & 57.17 & 42.16 & 58.85 & 68.00 & 0.000 \\
\hline Construct6 V3 & 59.64 & 31.34 & 52.60 & 62.00 & 0.000 \\
\hline Construct6 V4 & 59.19 & 41.42 & 61.98 & 65.00 & 0.000 \\
\hline Construct7 V1 & 58.86 & 45.52 & & 72.00 & 0.000 \\
\hline Construct7 V2 & 66.70 & 50.75 & & 72.00 & 0.000 \\
\hline Construct7 V3 & 59.75 & 42.91 & & 67.00 & 0.000 \\
\hline Construct8 V1 & 64.01 & 49.63 & & 64.00 & 0.000 \\
\hline Construct8 V2 & 60.31 & 47.39 & & 63.00 & 0.000 \\
\hline Construct8 V3 & 55.38 & 44.03 & & 57.00 & 0.000 \\
\hline Construct8 V4 & 53.03 & 42.16 & & 51.00 & 0.000 \\
\hline Construct9 V1 & 69.39 & 41.42 & & 66.00 & 0.000 \\
\hline Construct9 V2 & 62.00 & 36.94 & & 68.00 & 0.000 \\
\hline Construct9 V3 & 59.19 & 35.45 & & 61.00 & 0.000 \\
\hline Construct9 V4 & 57.51 & 36.57 & & 58.00 & 0.000 \\
\hline Construct10 V1 & 66.26 & 46.64 & & 75.00 & 0.000 \\
\hline Construct10 V2 & 60.54 & 40.67 & & 72.00 & 0.000 \\
\hline Construct10 V3 & 63.34 & 37.69 & & 70.00 & 0.000 \\
\hline Construct11 V1 & 66.82 & 47.01 & & 71.00 & 0.000 \\
\hline Construct11 V2 & 70.40 & 45.15 & & 73.00 & 0.000 \\
\hline Construct11 V3 & 71.30 & 42.91 & & 70.00 & 0.000 \\
\hline Construct11 V4 & 65.81 & 36.94 & & 64.00 & 0.000 \\
\hline Construct11 V5 & 60.65 & 34.70 & & 72.00 & 0.000 \\
\hline
\end{tabular}




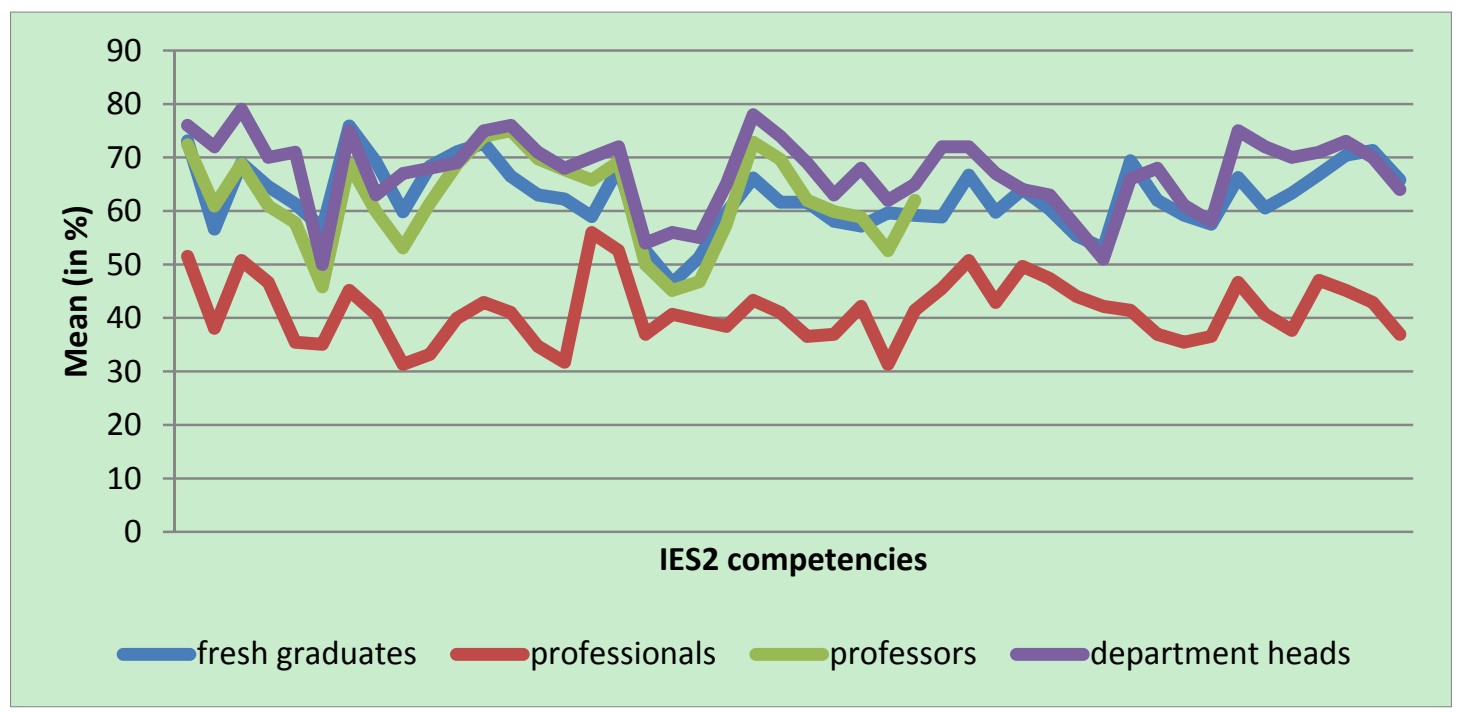

Figure 1. Means of IES 2 competencies for the students, professors, department heads, and professionals

Next, we evaluate the competencies of IES 3 in Table 28 and Chart 2. Here, the chart shows that the means of the professors, department heads, and professionals are overlapping while the means of the students are farther away. Those results show that the difference in evaluation in IES 3 is between the professors, department heads, and professionals on one side and the students on the other side. In addition, it demonstrates that the students might be overestimating their professional competencies.

Table 27. ANOVA test for IES 3 on the competency level

\begin{tabular}{llllll}
\hline IES 3 Competency & Students & CPA & Prof & Dept. Head & P-value \\
\hline Construct1 V1 & 70.29 & 44.78 & 60.71 & 64.58 & 0.000 \\
Construct1 V2 & 66.14 & 47.76 & 53.06 & 59.38 & 0.000 \\
Construct1 V3 & 65.58 & 44.78 & 60.00 & 62.00 & 0.000 \\
Construct1 V4 & 68.39 & 51.49 & 55.00 & 61.00 & 0.000 \\
Construct1 V5 & 65.47 & 47.76 & 52.00 & 54.00 & 0.000 \\
Construct2 V1 & 74.66 & 61.57 & 59.00 & 60.00 & 0.000 \\
Construct2 V2 & 67.38 & 60.45 & 54.50 & 59.00 & 0.000 \\
Construct2 V3 & 68.61 & 54.10 & 55.00 & 56.00 & 0.000 \\
Construct2 V4 & 74.22 & 56.34 & 55.50 & 60.00 & 0.000 \\
Construct2 V5 & 68.27 & 57.09 & 59.00 & 56.00 & 0.000 \\
Construct2 V6 & 72.87 & 55.97 & 63.00 & 63.00 & 0.000 \\
Construct3 V1 & 77.35 & 67.91 & 70.50 & 70.00 & 0.000 \\
Construct3 V2 & 73.88 & 62.69 & 63.00 & 65.00 & 0.000 \\
Construct3 V3 & 71.08 & 61.19 & 56.50 & 59.00 & 0.000 \\
Construct3 V4 & 71.30 & 61.94 & 58.00 & 60.00 & 0.000 \\
Construct3 V5 & 70.52 & 63.06 & 53.50 & 58.00 & 0.000 \\
Construct3 V6 & 70.40 & 61.57 & 52.50 & 54.00 & 0.000 \\
Construct3 V7 & 69.96 & 55.97 & 57.50 & 61.00 & 0.000 \\
Construct4 V1 & 70.96 & 62.31 & 61.50 & 64.00 & 0.000 \\
Construct4 V2 & 73.99 & 61.94 & 58.50 & 67.00 & 0.000 \\
Construct4 V3 & 71.19 & 54.85 & 58.00 & 57.00 & 0.000 \\
Construct4 V4 & 70.52 & 56.34 & 56.50 & 58.00 & 0.000 \\
Construct4 V5 & 67.83 & 55.60 & 53.50 & 58.00 & 0.000 \\
Construct4 V6 & 71.97 & 53.36 & 54.50 & 60.00 & 0.000 \\
\hline & & & & & \\
\hline
\end{tabular}




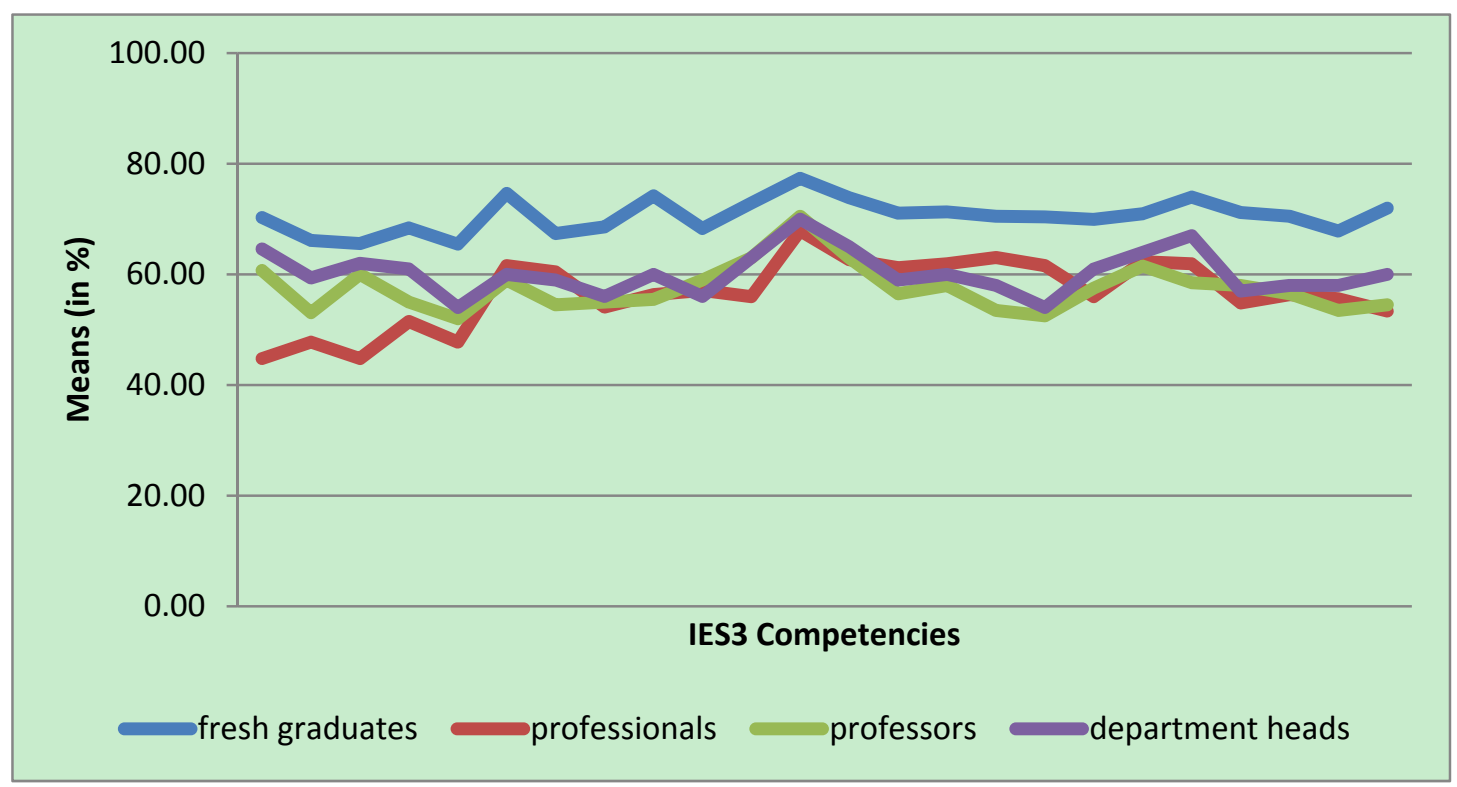

Figure 2. Means of IES 3 competencies for the students, professors, department heads, and professionals

Finally, Table 29 and Chart 3 represent the competencies of IES 4. For the majority of the means, the p-value is $>$ 0.05 . This signifies that the different groups have the same evaluation for most of these competencies. As for the remaining competencies - i.e., those with a $p$ value less than 0.05 - a closer look at the table shows that this time it is due to a discrepancy between the evaluation of students and professionals on one side and professors and department heads on the other side.

Table 28. ANOVA test for IES 4 on the competency level

\begin{tabular}{llllll}
\hline IES 4 competency & students & CPA & prof & depart. head & p-value \\
\hline Construct1 V1 & 66.93 & 57.09 & 54.50 & 59.00 & 0.000 \\
Construct1 V2 & 63.79 & 57.46 & 56.50 & 60.00 & 0.087 \\
Construct2 V1 & 69.17 & 61.57 & 64.00 & 66.00 & 0.09 \\
Construct2 V2 & 67.04 & 67.54 & 54.50 & 58.00 & 0.002 \\
Construct2 V3 & 67.04 & 62.69 & 61.00 & 66.00 & 0.287 \\
Construct2 V4 & 61.43 & 59.70 & 56.00 & 66.00 & 0.324 \\
Construct2 V5 & 68.39 & 67.54 & 53.50 & 62.00 & 0.001 \\
Construct2 V6 & 67.60 & 65.67 & 53.50 & 59.00 & 0.002 \\
Construct3 V1 & 65.81 & 65.30 & 63.00 & 63.00 & 0.84 \\
Construct3 V2 & 65.47 & 64.93 & 62.50 & 62.00 & 0.778 \\
Construct3 V3 & 60.54 & 61.94 & 61.00 & 61.00 & 0.979 \\
Construct3 V4 & 65.36 & 58.96 & 58.00 & 60.00 & 0.104 \\
\hline
\end{tabular}




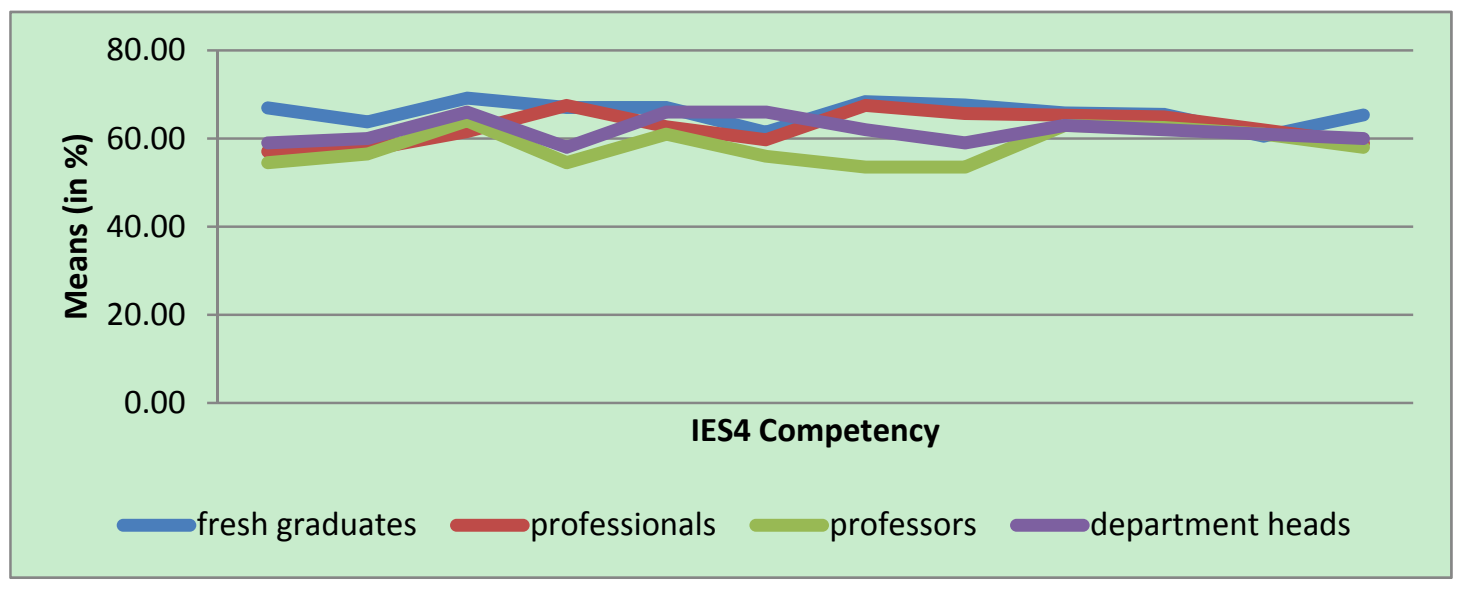

Figure 3. Means of IES 4 competencies for the students, professors, department heads, and professionals

\section{Conclusion and Recommendations}

In this article, we studied the gap between accounting education and practice in Lebanon within the framework of the International Education Standards set by the IFAC (particularly IES2, IES3, and IES4). We also set out to characterize this gap and provide suggestions for bridging it.

To achieve this goal, we developed a model that includes all the stakeholders, which together form the accounting education and practice in Lebanon. We also extracted a questionnaire from IES 2, IES3, and IES4 and distributed it among all the identified stakeholders in hope that the various competencies stipulated by these standards would be evaluated. We asked fresh graduates and employees to evaluate their own competencies, while asking professionals and educators to evaluate the competencies of the fresh graduates. In addition to the questionnaire, we conducted unstructured interviews with few professionals including the incumbent president of the LACPA and owners of CPA firms. We then evaluated the responses to the surveys using rigorous statistical tools.

Below, we summarize the key findings of this paper:

1) Standards are incorporated into the curriculum: Studying the curriculum theoretically shows that all the standards are incorporated in the different courses and that the competencies are covered by the courses but the empirical study (interviews and survey) is incompatible with the theory, as we explain below.

2) There is a gap in both technical and professional competencies: When Accounting professionals are asked to evaluate the technical competencies (accounting and generic) of fresh accounting graduates, they rank all of these competencies below average; this means that the proficiency of the graduates in these competencies is not at the level that is required by IAES that requires advanced to intermediate proficiency for most of the technical competencies. Furthermore, our surveys show that the employer's evaluation of the professional competencies of recent graduates is acceptable, while the students over-estimate their own professional competencies.

3) There is no gap in professional, values, ethics, and attitudes, competencies: The empirical study shows that the employers' evaluation of the professional, values, ethics, and attitudes, competencies are acceptable. This means that fresh accounting graduates are proficient enough in these competencies for the job market.

4) The university system is unaware of the extent of the gap in technical competencies: Academic stakeholders (both educators and students) over-estimate the level of technical competencies of accounting students in comparison to accounting professionals. This indicates that the university system is unaware of the extent of the gap in technical competencies.

5) Educators and professionals agree on the gap in professional competencies: Educators and professionals both agree on the inadequacy of professional competencies of accounting students. However, students are unaware of this gap.

From all the above findings, we provide the following recommendations for narrowing the gap between accounting education and practice in Lebanon:

1) Universities should have a virtual company, and the student should be taught how to deal with all the accounting transactions of the company, and then apply their knowledge to this virtual company. 
2) Students should be required to undergo training in accounting firms or accounting department of any firms, starting from the summer of their first year in the Bachelor's degree. This way, by the time of their graduation (i.e., after three years), they would have grasped the technical and practical aspects of accounting from their training, as well as the theory and critical thinking aspects at the university.

3) Universities should cooperate with the LACPA and some of the big CPA firms in the preparation of the curriculum and course contents. As for the courses related to taxes, universities should collaborate with specialized professionals in the subject of taxes.

We believe that implementing these recommendations would result in a positive impact at various levels. First, students will have more confidence when searching for a job. Second, companies will save time and money on training, especially that most of the Lebanese companies are family owned companies. Third, universities will have a curriculum that is better aligned with the requirements of the accounting job market.

In the future, it would be very interesting to explore how implementing our above recommendations would affect the various stakeholders in the accounting education and profession and how it would narrow the gap between them. We also envision that surveying employers' evaluation of employees at various stages of their careers may provide additional valuable information that can guide us in narrowing this gap.

\section{References}

Abayadeera, N., \& Watty, K. (2014). The expectation-performance gap in generic skills in accounting graduates: Evidence from Sri Lanka. Asian Review of Accounting, 22(1), 56-72. http://dx.doi.org/10.1108/ara-09-2013-0059

American Accounting Association. (1986). Future Accounting Education: Preparing for the Expanding Profession, American Accounting Association. Bedford Committee Report, 4, 12-20.

American Accounting Association. (1993). The Accounting Education Change Commission Issues Statement Number 5. Evaluating and Rewarding Effective Teaching.

American Accounting Association. (2012). The Pathways Commission on Higher Education: Charting a National Strategy for the Next Generation of Accountants.

Albrecht, W. S., \& Sack, R. J. (2000). Accounting education: Charting the course through a perilous future. American Accounting Association. Accounting Education Series, 16, 21-30.

Albrecht, W. S., \& Sack, R. J. (2001). The perilous future of accounting education. The CPA Journal, 71(3), 16-23.

Al-Jalily, \& Taha. (2010). The use of International Education Standards for professional accountants in developing the accounting curriculum for bachelor stage in Iraq. Tanmiyat al Rafidayn, 99(32).

Binh, B., \& Porter, B. (2010). The expectation-performance gap in accounting education: An exploratory study. Accounting Education: An International Journal, 19(1-2), 23-50.

Carifio, J., \& Rocco, J. P. (2000). Ten common misunderstandings, misconceptions, persistent myths and urban legends about Likert scales and Likert response formats and their antidotes. Journal of Social Sciences, 3(3), 106-116.

Center for Educational Research and Development. (n.d.). Statistics Bulletin. Retrieved September 9, 2015 from http://www.crdp.org/en/statistics-bulletin

Chua, W. F., \& Baxter, J. (2000). Management accounting-Beyond 2000. Pacific Accounting Review, 11(2), 54-65.

Civil Service Board. (n.d.) Examination Results. Retrieved September 9, 2015 from http://www.csb.gov.lb/Examination/ResultsT2.aspx?res=700

Dean, P. C., \& Campbell, J. (2010). What do companies expect of accounting majors. Review of Higher Education \& Self-Learning, 3(7), 101.

Donovan, C. (2005). The benefits of academic/practitioner collaboration. Accounting Education: An International Journal, 14(4), 445-452.

Epstein, M., \& Lee, J. (2011). Advances in management accounting. London: Emerald Group. http://dx.doi.org/10.1108/S1474-7871(2011)19

French, G. R., \& Coppage, R. E. (2000). Educational issues challenging the future of the accounting profession. Ohio CPA Journal, 59(3), 69-73. 
Gliem, J., \& Gliem, R. (2003). Calculating, interpreting, and reporting Cronbach's alpha reliability coefficient for Likert-type scales presented at the Midwest research-to-practice conference in adult, continuing, and community Education. The Ohio State University, Columbus, $\mathrm{OH}$.

Hancock et al. (2010). Accounting for the future accounting education at a crossroad in 2010. The Institute of Chartered of Accountants in Australia.

Hargadon, J. (2000). Accounting education: The challenges ahead. PICPA Special Insert, Special Millennium Insert. AICPA. New York, NY.

Hasrouny, A. (2011). LEBANON: Higher education at risk without reform. University World News, 155.

Howieson, B. (2003). Accounting practice in the new millennium: Is accounting education ready to meet the challenge? The British Accounting Review, 35(2), 69-103.

Kasparian, C. (2009). CARIM Mediterranean Migration Report 2008-2009. Robert Schuman Center for Advanced Studies, San Domenico Di Fiesole (FI): European University Institute.

Kavanagh, M., \& Drennan, L. (2008). What skills and attributes does an accounting graduate need? Evidence from student perceptions and employer expectations. Accounting \& Finance, 48(2), 279-300. http://dx.doi.org/10.1111/j.1467-629X.2007.00245.x

Kennedy, T., \& Bull, R. (2000). The great debate. Management Accounting (London), 78(5), 32-33.

Klibi1 M. F., \& Oussii, A. A. (2013). Skills and attributes needed for success in accounting career: Do employers' expectations fit with students' perceptions? Evidence from Tunisia. International Journal of Business and Management, 8(8). http://dx.doi.org/10.5539/ijbm.v8n8p118

Mandilas, A., Kourtidis, D., \& Petasakis, Y. (2014). Accounting curriculum and market needs. Education + Training, 56(8/9), 776-794.

Mohamed, E. K. A., \& Lashine, S. H. (2003). Accounting knowledge and skills and the challenges of a global business environment. Managerial Finance, 29(7), 3-16. http://dx.doi.org/10.1108/03074350310768319

Nahas, C. (2010). Finance and political economy of higher education in Lebanon. Economic Research Forum prr (policy Research Report), 34.

Novin, A. M., Pearson, M. A., \& Senge, S. V. (1990). Improving the curriculum for aspiring management accountants: The practitioner's point of view. Journal of Accounting Education, 8, 207-224. http://dx.doi.org/10.1016/0748-5751(90)90003-P

Parker, L. D. (2010). Introducing the Commercialised University Environment: Preliminary Reflections on the trajectory of change accounting education at a crossroad in 2010. The Institute of Chartered of Accountants in Australia, p. 16.

Romanus Okolie Onyeisi. (2014). The challenges of accounting education: The Nigerian experience. Accounting and Finance Research, 3(2).

Siegel, G., Sorensen, J. M., Klammer, T., \& Richtermeyer, S. B. (2010). The ongoing preparation gap in accounting education: A call to action. Management Accounting Quarterly, 11(3), 41-51.

Sikka, P., Haslam, C., Kyriacou, O., \& Agrizzi, D. (2007). Professionalizing claims and the state of UK professional accounting education: Some evidence, accounting education. An International Journal, 16(1), 3-22.

Swanson, R. (1999). Is management accounting a dead profession? Strategic Finance, 81(1), 6.

Tabar, P. (2009). Immigration and Human Development: Evidence from Lebanon. United Nations Development Programme Human Development Reports Research Paper 2009/35 August 2009.

Tudor, A. T., \& Mutiu, A. I. (2007). Toward a global accounting education in Europe. International Journal of Business Research, 7(1).

Wahida Zraa et al. (2011). Teaching accounting in the new millennium. Cambridge Business and Economics Conference (CBEC).

Watson, S. F., Apostolou, B., Hassell, J. M., \& Webber, S. A. (2001). Accounting education literature review (1997-1999). Journal of Accounting Education, 1, 1-61.

Young, D. W. (2003). Management accounting in health care organizations. San Francisco, CA: Jossey-Bass.

Zumbo, B. D., \& Zimmerman, D. W. (1993). Is the selection of statistical methods governed by level of 
measurement? Canadian Psychology, 34, 390-400. http://dx.doi.org/10.1037/h0078865

\section{Note}

Note 1. B. D. Zumbo and D. W. Zimmerman (1993) argued that the power functions for the T-tests on the ordinal representations are very similar to the power functions for the nonparametric Wilcoxon-Mann-Whitney test. This indicates that there is no benefit to be gained from excluding the use of parametric statistics on ordinal data. These findings are also true for various sample sizes and significance level. In another study, the authors emphasized that the of use of a 5- to 7-point Likert response format is as correct and reasonable as using parametric analysis, such as F-ratio or Pearson correlation coefficients, when analyzing the results (James Carifio \& Rocco J. Perla, 2007). These arguments validate our use of the ANOVA and T-test as statistical tools.

\section{Appendix A}

Detailed constructs (i.e., areas of competencies) and the variables (i.e., the items related to these competencies) that compose them

IES 2 technical competencies

1- Apply accounting principles to transactions and other events

2- Apply IFRS or other relevant standards to a range of transactions and other events

Technical competencies 1: Financial 3-Classify financial data appropriately in financial statements accounting and reporting (Construct 1)

4- Prepare primary statements, financial including financial statements, in accordance with consolidated laws and regulations

5- Evaluate the appropriateness of accounting policies used to prepare financial statements

6- Interpret specialized reports, including sustainability reports and integrated reports

1- Apply techniques such as product costing, variance analysis, inventory management, and budgeting and forecasting to improve the performance of an organization

Technical competencies 2: Management 2- Analyze and integrate financial and nonfinancial data to provide relevant information for accounting managerial decision making

(Construct 2)

3- Prepare reports to support managerial decision making, including reports that focus on planning and budgeting, cost management, quality control, performance measurement, and benchmarking

4- Compare and evaluate the performance of products and business segments

1- Compare the various sources of finance available to an organization, including banking finance, financial instruments, and different capital markets

2- Analyze an organization's cash flow and working capital requirements

3- Analyze the current and future financial position of an organization, using techniques

Technical competencies 3: Finance and financial management

(Construct 3)

4- Evaluate the appropriateness of the components used to calculate an organization's cost of capital

5- Apply appropriate capital budgeting techniques to the evaluation of capital investment decisions

1- Explain domestic taxation compliance requirements and filing

Technical competencies 4: Taxation 2-Prepare tax calculations for direct and indirect taxes for individuals and organizations

(Construct 4)

3- Analyze the taxation issues associated with non-complex international transactions

4- Explain the difference between tax planning, tax avoidance, and tax evasion

5- Identify when it is appropriate to refer matters to taxation specialists

1-Analyze the risk profile of an entity to identify the components of audit risk

Technical competencies 5: Audit and 2-Describe the objectives of an audit of financial statements

assurance (Construct 5)

3- Describe the activities involved in performing an audit of financial statements

4- Identify applicable auditing standards (e.g., ISAs), laws, and regulations relevant to an audit engagement

1- Explain the principles of good governance, including the rights and responsibilities of

Technical competencies 6: Governance, risk management, and internal control (Construct 6) owners, and the role of stakeholders in governance, disclosure, and transparency requirements

2- Analyze the components of an organization's governance structure

3- Analyze an organization's risks and opportunities within a risk management framework 
4- Analyze the components of internal control

Technical competencies 7: Business laws and regulations (Construct 7 )

Technical competencies 9: Business and organizational environment (Construct 9)

Technical competencies 10: Economics (Construct 10)

Technical competencies 11: Business management (Construct 11)

\section{IES 3 Professional skills}

Professional competencies 1: Intellectual (Construct 12)

Professional competencies 2: Personal (Construct 13)

Professional competencies 3: Interpersonal and communication (Construct 14)
1-Explain the laws and regulations that are relevant to the environment in which professional accountants operate

2- Explain different legal forms of businesses and the legislation and regulations that govern each form

3- Identify when it is appropriate to refer matters to legal specialists for help

1 - Describe the basic hardware and software components of information systems

2- Identify general computer controls and application controls required for effective accounting information systems

3- Analyze the adequacy of controls for relevant application systems

4- Explain the components of an information system's continuity plan

1- Describe the environment in which an organization operates, including the main economic, legal, political, social, technical, international, and cultural forces and their influences and values

2- Analyze key features in the global environment that affect international trade and finance 3- Explain the impact of legal, political, cultural, and technological contexts on the processes of the internationalization of an organization

4- Identify the characteristic features of globalization, including the role of multinationals, e-commerce, and emerging markets

1-Describe the fundamental principles of microeconomics and macroeconomics

2- Interpret the effect of movements in key indicators of microeconomic and macroeconomic activity

3- Explain the competitive environment facing organizations under different types of market structures, including competitive markets, monopoly, monopolistic competition, and oligopoly

1- Explain the various ways that organizations may be designed and structured

2- Explain the purpose and importance of functional areas, such as human resource management, project management, procurement, technology management, and marketing 3-Explain the external and internal factors that may influence the formulation of an organization's strategy

4- Analyze relevant factors in the internal and external business environment that impact on managerial work and organizational performance

5- Compare how various theories of organizational behavior may be used to enhance the performance of the individual, teams, and the organization

1- Evaluate information from a variety of sources and perspectives through research, analysis, and integration

2- Identification and evaluation of alternatives to reach well-reasoned conclusions based on all relevant facts and circumstances

3- Identify when it is appropriate to consult with specialists to solve problems and reach conclusions

4- Apply reasoning, critical analysis, and innovative thinking to solve problems

5- Recommend solutions to unstructured, multi-faceted problems

1- Demonstrate a commitment to lifelong learning

2- Apply professional skepticism through questioning and critically assessing all information

3- Set high personal standards of delivery and monitor personal performance through feedback from others and reflection

4- Manage time and resources to achieve professional commitments

5- Anticipate challenges and plan potential solutions

6- Apply an open mind to new opportunities

1- Display cooperation and teamwork when working toward organizational goals

2- Communicate clearly and concisely when presenting, discussing, and reporting in formal and informal situations, both in written and oral communication

3- Demonstrate awareness of cultural and language differences in all communication

4- Apply active listening and effective interviewing techniques 
5- Apply negotiation skills to reach solutions and agreements

6- Apply consultative skills to minimize or resolve conflict, solve problems, and maximize opportunities

7- Present ideas and influence others to provide support and commitment

Professional competencies 4: Organizational 1- Undertake assignments in accordance with established practices to meet prescribed (Construct 15) deadlines

2- Review one's own work and that of others to determine whether it complies with the organization's quality standards

3- Apply people management skills to motivate and develop others

4- Apply delegation skills to deliver assignments

5- Apply leadership skills to influence others to work toward organizational goals

6- Apply appropriate tools and technology to increase efficiency and effectiveness and improve decision making

IES 4 professional values, ethics, and attitudes

Ethical competencies 1: Professional 1- Apply a questioning mindset critically to assess financial information and other relevant skepticism and professional judgment data

(Construct 16)

2- Identify and evaluate reasonable alternatives to reach well-reasoned conclusions based on all relevant facts and circumstances

Ethical competencies 2: Ethical principles (Construct 17)

1- Explain the nature of ethics

2- Explain the advantages and disadvantages of rules-based and principles-based approaches to ethics

3- Identify ethical issues and determine when ethical principles apply

4- Analyze alternative courses of action and determine the ethical consequences of these alternatives

5-Apply the fundamental ethical principles of integrity, objectivity, professional competence, due care, confidentiality, and professional behavior to ethical dilemmas and determine an appropriate approach

6- Apply the relevant ethical requirements to professional behavior and compliance with standards

Ethical competencies 3: Commitment to the 1- Explain the role of ethics within the profession and in relation to the concept of social public interest (Construct 18) responsibility

2- Explain the role of ethics in relation to business and good governance

3- Analyze the interrelationship of ethics and law, including the relationship between laws, regulations, and the public interest

4- Compare the consequences of unethical behavior for the individual, the profession, and the public

\section{Appendix B}

Mapping the curriculum to the IES

In this appendix, we map the courses of the accounting curriculum of the Lebanese University to the related competences.

\begin{tabular}{ll}
\hline Competencies & Courses that Cover the Competency \\
\hline IES 2 - Technical Competencies & \\
1- Financial accounting and reporting & Financial Analysis, Financial Management, Feasibility Study, Accounting 1, Accounting 2, \\
& Accounting Systems, International Accounting Standards, International Audit Standards (IAS, \\
& IFRS, ISA, ISCQ1, IAPS, ISAE). Corporate Accounting, Partnership Accounting \\
& Statistics 1, Feasibility Study, Data Analysis, Managerial Control, Quantitative Methods, \\
2- Management accounting & Research Techniques, Cost Accounting 1, Cost Accounting 2, Financial Mathematics, \\
& Operations Research, Principles of Management \\
& Financial Management, Financial Analysis, Feasibility Study, Financial Mathematics \\
3- Finance and financial management & Tax Accounting. \\
4- Taxation & Methods of Control, Internal Audit, External Audit, International Auditing Standards (IAS, \\
5- Audit and assurance &
\end{tabular}


IFRS, ISA, ISCQ1, IAPS, ISAE)

6-Governance, risk management, and Internal Audit, Financial Management, Feasibility Study, Managerial Control, Methods of internal control

Control, Financial Institutions Control Techniques, International Auditing Standards (IAS, IFRS, ISA, ISCQ1, IAPS, ISAE)

7- Business laws and regulations Business Law, Public Finance, Strategic Management. Labor and Social Security Law, Banking Regulations

8- Information technology

Computer Applications, Information Technology, Management Information System

9- Business and organizational environment

Managerial Control, Customs and Maritime Law, Principles of Management, Strategic Management, Banking Regulations, Labor and Social Security Law

10- Economics

11- Business management

Microeconomics and Macroeconomics

Managerial Control, Principles of Marketing, Principles of Management, Human Resources Management

IES 3 Professional Skills

Courses

Intellectual,

Each course taught should add to all these skills, and by the end of the education period, the

Personal,

student should acquire all these skills

Interpersonal and Communication,

Organizational

3 IES 4 Professional Values, Ethics, and Courses

Attitudes

Professional skepticism and professional judgment, Ethical principles, Commitment

These competencies should be taught in the auditing courses as well as in the business ethics to the public interest

\section{Copyrights}

Copyright for this article is retained by the author(s), with first publication rights granted to the journal.

This is an open-access article distributed under the terms and conditions of the Creative Commons Attribution license (http://creativecommons.org/licenses/by/3.0/). 